\title{
Perempuan dalam Iklan Pariwisata Indonesia
}

\author{
Arista Nur Widiastuti \\ Fakultas Komuikasi dan Informatika, Universitas Muhammadiyah Surakarta, J1. A. Yani Tromol Pos I \\ Pabelan, Kartasura, Surakarta 57102 \\ E-mail : aristhawidi25@gmail.com
}

\begin{abstract}
Abstrak: Penelitian mengenai gender di iklan sudah banyak dilakukan, namun lebih difokuskan pada penelitian kuantitatif. Penelitian pariwisata dilakukan karena berhubungan dengan kultur. Iklan pariwisata menunjukkan berbagai aktivitas atau kegiatan masyarakat yang mereka lakukan, termasuk berbagai budaya yang ada di setiap daerah dan hal tersebut juga berkaitan dengan peran sosial. Penelitian ini merupakan penelitian deskriptif kualitatif dengan mengunakan teknik analisis isi karena ingin meneliti mengenai penggambaran perempuan di iklan pariwisata. Penelitian dilakukan dengan pendekatan deduktif dari kategorisasi gender advertisment menurut Goffman. Kategorisasi Goffman (1979) terdiri dari Relative Size, Feminin Touch, Function Rank, The Family, Ritualization of Subordination dan juga Licenced Withdrawal. Objek penelitian ini ialah iklan pariwisata Indonesia yang diunggah di akun Youtube Indonesia. Travel sejak tahun 2010, dan jumlahnya ada 211 video. Sampel iklan yang akan dianalisis berjumlah sepuluh video. Iklan tersebut diambil dengan teknik purposif serta dilanjutkan dengan random. Hasil penelitian menunjukkan bahwa masih ada penggambaran perempuan yang mempertahankan peran stereotipe tradisional, namun juga ada kategori yang sudah mulai menunjukkan perempuan keluar dari peran stereotipe.
\end{abstract}

Kata kunci: gender, pariwisata, perempuan, stereotip.

\begin{abstract}
Research about gender in advertising has already done a lot, but it more focused on quantitative research. Tourism research being conducted because it relates to culture. Tourism ads showed tourism activities carried out by the community, included many different cultures in each area and this is also relates to social roles. This research is a descriptive qualitative research by using content analysis to examine about the portrayal of women in the tourism advertising. The study was conducted by the deductive approach of gender advertisment categorization according to Goffman. Categorization of Goffman (1979) consisted of Relative Size, Feminine Touch, Function Rank, The Ritualization of Subordination, The Family and Licenced Withdrawal. The object of this research is Indonesia's tourism ads uploaded in youtube accounts "Indonesia.Travel", since 2010, there are 211 videos uploaded on the account. The samples used for the research are 10 videos. The ads are taken with the technique of purposive and continued by random. The results showed that there is still a depiction of women who defended the role of traditional stereotype, but there are categories that is already starting to show the woman out of the role of stereotype.
\end{abstract}

Keywords: gender, tourism, women, stereotypes 


\section{PENDAHULUAN}

Mengembangkan

pariwisata termasuk cara untuk memajukan suatu daerah agar dapat meningkatkan pendapatan serta dikenal oleh banyak orang. Gender sebagai dimensi sosial mempunyai makna dalam industri pariwisata. Aitchison (dalam Pritchard, 2001) berpendapat bahwa pariwisata ialah produk dari gender sosial dimana proses pariwisata merupakan konstruksi dari presentasi dan konstruksi gender. Gender merupakan sistem identitas budaya serta hubungan sosial antara lakilaki dan perempuan.

Pemahaman mengenai gender berhubungan dengan budaya masyarakat ketika mengaitkannya dengan peran lakilaki dan perempuan. Indonesia sudah memiliki UUD 1945 yang mengatur mengenai kesamaan hak seluruh warga negara, sehingga di Indonesia dianggap tidak ada masalah mengenai ketidakadilan gender. Namun cara pandang masyarakat mengenai peran perempuan masih dipengaruhi oleh stereotip tradisional, yaitu perempuan ditempatkan pada peran domestik seperti mendampingi suami dan mengasuh anak-anak (Kusuma \& Vitasari, 2017). Hal tersebut yang menyebabkan budaya mengenai perempuan dianggap sebagai pengurus rumah tangga masih bertahan dimasyarakat.

Banyak hal yang membantu dalam mengontruksi gender. Salah satunya ialah media massa dalam bentuk periklanan. Iklan mengomunikasikan kebiasaan atau kultur dari suatu budaya. Iklan pariwisata menunjukkan berbagai aktivitas atau kegiatan masyarakat yang mereka lakukan, termasuk berbagai budaya yang ada di setiap daerah dan hal tersebut juga berkaitan dengan peran sosial. Gambar gender di periklanan dianggap sebagai cerminan dari konstruksi sosial budaya. Iklan pariwisata memanfaatkan gender agar dapat berkomunikasi dengan lebih efektif kepada target pasar. Secara sosial, pesan ditujukan kepada laki-laki dan perempuan sehingga iklan diidealisasikan dengan peran dan hubungan tertentu untuk menarik konsumen. (Pritchard, 2001).

Studi mengenai gender di periklanan sudah banyak dilakukan sejak Goffman melakukan penelitiannya mengenai gambar gender dalam iklan (Sun, 2017). Iklan media cetak masih sering mengambarkan laki-laki dan perempuan dengan stereotip, yaitu perempuan sebagai makluk yang terlalu rendah, patuh serta bergantung pada lakilaki dan penggambaran laki-laki yang berkebalikan dengan penggambaran perempuan (Sirikaya \& Sonmez, 2015). Media periklanan ini tidak berjalan dengan cepat dalam menampilkan perubahan penggambaran laki-laki dan perempuan (Wagner \& Banos, 1973).

Setelah menganalisis display iklan, Goffman berpendapat bahwa laki-laki dan perempuan berulang kali digambarkan dalam ritual sosial pada suatu adegan. Pada buku Goffman (1979) yang berjudul Gender Advertisements dituliskan bahwa ia mengelompokkan penggambaran perilaku yang ditampilkan dalam iklan menjadi enam kategori, yang terdiri atas: (1) Relative size lebih mengacu pada tampilan fisik. Hal ini ditentukan dengan membandingkan "tinggi" dari pihakpihak yang ada di dalam iklan. Lebih tinggi diasumsikan memiliki kekuatan yang lebih banyak, dan Goffman mengasumsikan bahwa perbedaan ukuran orang berkorelasi dengan perbedaan bobot sosial. (2) Feminine Touch melibatkan penggunaan jari dan tangan dalam menyentuh benda. Goffman mengatakan bahwa sentuhan yang lembut dan indah dibedakan dari penggaan tangan atau jari saat mengenggam atau memegang. (3) Function rank mengelompokkan perilaku dari model dalam iklan yang biasanya ditampilkan melakukan berbagai tugas. Pentingnya 
tugas yang dilakukan oleh orang yang terlibat, menunjukan kepentingan sosial seseorang. (4) The family juga menggambarkan struktur sosial dan budaya tertentu. (5) Ritualization of subordination mendefinisikan tindakan sebagai perbuatan subordinasi dengan menurunkan diri secara fisik ke orang lain. Hal ini menyampaikan gagasan tentang hubungan gender yang superordinasi dan subordinasi. (6) Licensed withdrawal perilaku dimana karakter tidak dapat menguasai situasi, dan lebih bergantung pada karakter lain.

Pemasaran pariwisata salah satunya dapat dilakukan dengan promosi menggunakan media bisa berupa gambar maupun video. Penggambaran pariwisata dibuat, disaring dan dimediasi oleh budaya dan struktur ideologi. Nixon (dalam Pitchard, 2001) telah menunjukkan bahwa budaya periklanan sudah lama di dominasi oleh laki-laki. Periklanan pariwisata memanfaatkan penggambaran gender untuk menarik audiens. Gender sebagai suatu dimensi sosial yang menyusun hampir seluruh aspek pariwisata.

Penelitian terdahulu mengenai gender dalam iklan pariwisata dilakukan oleh Pritchard (2001) dengan menganalisis gambar laki-laki dan perempuan pada pemasaran pariwisata. Hasil tulisannya berpendapat bahwa promosi pariwisata sangat patriarkal. Laki-laki ditampilkan lebih otoritas atau aktif sedangkan perempuan digambarkan dengan baik dalam peran rumah tangga. Menurut Pritchard (2001), sepuluh tahun lalu, perempuan berada di kolam renang dengan menggunakan bikini, dan sekarang mereka sudah mulai digambarkan secara atletis dan sporty akan tetapi daya tarik seksualnya masih tetap ada dan penting.

Studi ini akan meneliti iklan pariwisata yang ada di Indonesia. Pemerintah Indonesia telah menetapkan Wonderful Indonesia sebagai brand baru pariwisata Indonesia pada tahun 2011. Wonderful Indonesia telah melakukan promosi-promosi melalui iklan televisi, media cetak maupun Internet. Salah satu media promosi Wonderful Indonesia yang digunakan untuk mengiklankan pariwisata yaitu youtube dengan nama akun Indonesia.Travel. Akun tersebut ialah akun resmi milik Kementrian Kebudayaan dan Pariwisata Indonesia yang digunakan untuk mempromosikan keindahan wisata Indonesia. Saat ini akun tersebut telah mengunggah lebih dari 200 video sejak tahun 2010 silam. Penelitian ini dilakukan dengan menganalisis isi iklan untuk memeriksa penggambaran perempuan yang menjadi objek iklan. Iklan yang akan diteliti yaitu iklan Wonderful Indonesia yang menampilkan laki-laki dan perempuan. Peneliti memilih Indonesia.Travel karena akun tersebut telah aktif mempromosikan Indonesia terutama di channel youtube.

Penelitian sebelumnya yang dilakukan Sun (2017) telah menganalisis isi iklan pariwisata kota perjudian Macau dengan metode kuantitatif. Penelitian menguji penggambaran gender dalam iklan pariwisata Macau dan diungkapkan pola representasi gender dalam pariwisata. Penelitian ini sama dengan penelitian yang dilakukan Sun (2017), yaitu menganalisis isi iklan pariwisata untuk melihat penggambaran gender, namun lebih di fokuskan pada perempuan. Penelitian ini menggunakan metode analisis isi kualitatif untuk menganalisis gambar visual isi pesan karena peneliti ingin mencari tahu lebih dalam megenai penggambaran perempuan dalam iklan Wonderful Indonesia. Peneliti akan menganalisis konten visual penggambaran perempuan dalam iklan dengan menggunakan enam kategori gender di periklanan yang diklasifikasikan oleh Goffman. Berdasarkan latar belakang tersebut, peneliti akan melihat bagaimana penggambaran perempuan dalam iklan 
pariwisata Wonderful Indonesia yang diunggah di akun youtube Indonesia. Travel?

\section{METODE}

Penelitian ini termasuk penelitian deskriptif kualitatif. Objek yang diteliti ialah iklan pariwisata Indonesia yang telah diunggah di akun youtube Indonesia. Travel. Populasi penelitian ialah seluruh iklan yang telah diunggah pada akun tersebut hingga akhir November 2017 dan jumlahnya ada 211 video. Pengambilan sampel dilakukan dengan dua teknik sampling yaitu purposif dan dilanjutkan dengan random. Purposif dilakukan dengan mengambil iklan yang menampilkan laki-laki dan perempuan yang diposting sejak tahun 2011 karena sejak tahun tersebut Wonderful Indonesia baru dibentuk. Selain itu, karena peneliti akan menganalisis iklan pariwisata Wonderful Indonesia, maka iklan yang dijadikan sampel penelitian ialah iklan yang diposting dengan logo Wonderful Indonesia dan Pesona Indonesia. Iklan yang diambil yaitu iklan yang mempromosikan destinasi pariwisata non dokumenter, bukan untuk mempromosikan produk, jasa maupun event tertentu. Dari total seluruh iklan, setelah di seleksi dapat diambil 50 sampel iklan. Kemudian untuk mempermudah penelitian, sampel di persempit lagi dengan mengambil 10 iklan menggunakan teknik random. Unit analisis video yang diteliti ialah gambar visualnya.

Metode pengumpulan data yang digunakan oleh peneliti ialah dokumentasi dengan mengumpulkan iklan-iklan yang diunggah di akun Youtube Indonesia. Travel sejak tahun 2010 silam. Selain itu untuk mendukung analisis data, peneliti juga dibantu dengan literatur data dari sumber lain berupa buku-buku dan juga jurnal penelitian terdahulu. Analisis data yang digunakan ialah analisis isi kualitatif. Pada penelitian ini peneliti menggunakan teknik validitas intercoder yang dilakukan dengan mengevaluasi hasil analisis peneliti dengan peneliti kedua menggunakan pengodean, hal ini untuk melihat sejauh mana kesamaan evaluasi antar peneliti (Lombard, Duch, \& Bracken, 2002). ). Alasan memilih peneliti kedua ialah peneliti tersebut berpengalaman dibidang yang sama dan juga penelitiannya sejenis.

\section{HASIL DAN PEMBAHASAN}

Sepuluh video yang diunggah oleh Kementrian Kebudayaan dan Pariwisata Indonesia di akun youtube Indonesia. Travel telah dianalisis secara deduktif mengunakan teori gender dalam iklan dari Erving Goffman. Pada penelitian sebelumnya yang dilakukan oleh Belknap \& Il, 1991; Sirikaya \& Sonmez, 2015; Bell \& Milic, 2002 telah ditemukan enam kategori yang terdiri dari Relative Size, Feminine Touch, Function Rank, The family, Ritualization of subordination, dan Licensed withdrawal. Pada penelitian ini, video Wonderful Indonesia juga akan dibahas dengan enam kategori yang sama.

\section{Relative Size}

Relative sizel ukuran relatif, mengacu pada ukuran secara fisik seperti tinggi badan. Secara biologis tinggi tubuh laki-laki dan perempuan yang seumuran biasanya lebih tinggi laki-laki. Orang yang memiliki ukuran tubuh lebih

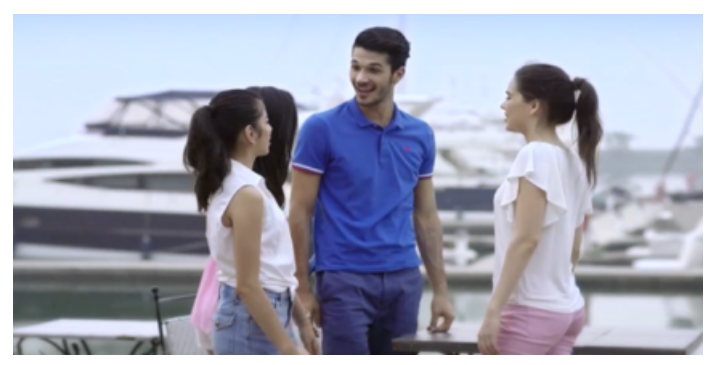

GAMBAR 1. Wonderful Indonesia Business (Japanese Version) (Perempuan ditunjukkan memiliki ukuran tubuh lebih rendah dari pada tubuh laki-laki) 


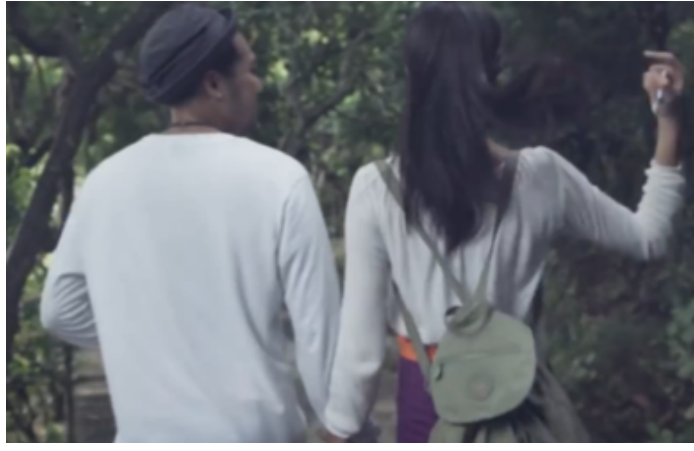

GAMBAR 2. Wonderful Indonesia - Explore The Journey of Romance 60s ( Laki-laki dan perempuan ditunjukkan dengan tinggi yang sejajar)

tinggi, melambangkan keunggulan kelas sosial yang berupa kekuatan, wewenang, jabatan dan lain-lain. Ukuran relatif antara laki-laki dan perempuan bisa diatur dan bahkan sering kali dilebihlebihkan melalui sudut pandang kamera (Sirikaya \& Sonmez, 2015 ). Relative size berpengaruh terhadap bias gender sebab pada situasi sosial tertentu seseorang dapat diseleksi melalui ukuran relatif atau tinggi tubuhnya. Karena itulah orang yang memiliki tubuh lebih tinggi akan memiliki peluang lebih tinggi. Misalkan dalam hal pekerjaan, pada posisi atau pekerjaan tertentu seseorang harus memiliki batas tinggi minimal yang belum tentu dimiliki oleh semua orang (Goffman, 1979).

Berdasarkan sepuluh iklan Wonderful Indonesia yang telah diteliti, salah satu video (gambar 1) ditunjukkan bahwa tubuh laki-laki ditunjukkan lebih tinggi dibandingkan dengan tinggi tubuh perempuan. Orang yang memiliki tubuh lebih tinggi, diasumsikan memiliki kekuatan yang lebih banyak. Pada iklan tersebut laki-laki ditunjukkan memiliki kekuatan serta wewenang lebih tinggi dibandingkan dengan pemeran perempuannya. Namun dari beberapa iklan tersebut tidak hanya laki-laki yang ditunjukkan lebih tinggi. Ada beberapa video yang juga menunjukkan bahwa laki-laki dan perempuan memiliki tinggi yang sama dan sejajar (gambar 2). Laki-

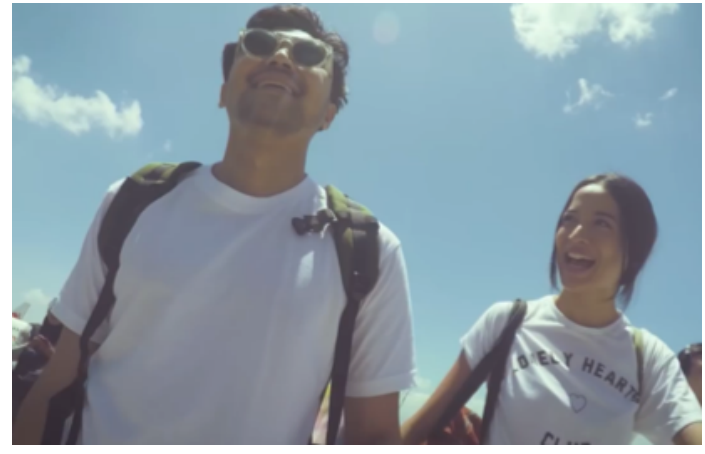

GAMBAR 3. Wonderful Indonesia - Explore The Journey of Romance 60s (Laki-laki ditunjukkan lebih tinggi dengan sudut pengambilan gambar yang berbeda)

laki dan perempuan yang memiliki tinggi sejajar dianggap memiliki kekuatan serta wewenang yang sama.

Video yang menunjukkan ukuran tubuh yang lebih tinggi bisa dibuat-buat dengan sudut pandang kamera. Dari video seluruh sampel yang telah diteliti ada beberapa video yang menunjukkan tinggi tubuh seseorang yang ditunjukkan berbeda dengan sudut pengambilan gambar yang berbeda. Ada video yang menunjukkan bahwa perempuan ditunjukkan dengan ukuran tubuh yang lebih rendah dari pada laki-laki dengan angle kamera. Pada beberapa scene ditunjukkan bahwa tinggi tubuh lakilaki dan perempuan sebenaranya sama (gambar 2), namun pada scene yang lain (gambar 3) ukuran relatif tubuh perempuan ditunjukkan lebih rendah dari pada laki-laki. Dari video tersebut dapat dilihat bahwa dalam suatu iklan, pemeran laki-laki berusaha ditunjukkan dengan status sosial yang lebih tinggi dari pada perempuan.

\section{Feminin Touch}

Feminin touch/ sentuhan feminin melibatkan penggunaan jari dan tangan dalam menyentuh benda. Menurut Goffman pada penelitian Belknap \& II (1991) sentuhan secara ritualistik menjadikan seseorang merasa menjadi lembut dan berharga. Sentuhan Menurut 
penelitian yang dilakukan oleh Goffman (1979), dibandingkan dengan lakilaki, perempuan lebih sering bermain menggunakan tangan dan jari mereka untuk menyentuh benda, atau membelai permukaannya. Penggunaan jari tangan dapat menunjukkan kelembutan diri dan juga keagrsifan (Sirikaya \& Sonmez, 2015 ).

Penelitian terhadap sepuluh video iklan Wonderful Indonesia beberapa diantaranya ditemukan bahwa perempuan menggunakan tangan atau jarinya untuk menyentuh, memegang atau memainkan sesuatu dengan jari tangannya. Perempuan menyentuh suatu benda seperti kain, tanaman dan air dengan pelan-pelan (gambar 4). Dan ketika memegang buah dan batu ia hanya menggunakan dua jarinya, yaitu jempol dan telunjuk. Selain itu perempuan juga menyentuh laki-laki dan mengibaskan rambut dengan jari tangannya. Dari hal tersebut dapat dilihat bahwa perempuan ditunjukkan dalam video sebagai sosok yang lembut dengan menyentuh barang secara berhati-hati dan memegang barang dengan jari-jarinya. Perempuan juga dilihat sebagai pihak yang agresif. Hal ini dilihat dari tangan perempuan yang menyentuh laki-laki dan membelai dengan jarinya (gambar 5).

Hasil lain yang ditunjukkan pada beberapa sampel video Wonderful Indonesia ialah sentuhan diri. Dari beberapa video, ada adegan perempuan yang menunjukkan dirinya menyentuh

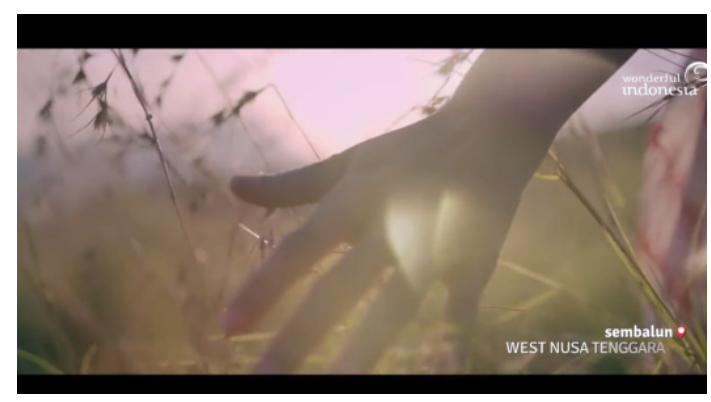

GAMBAR 4. Explore Further and Higher in the World of Wonders (Tangan perempuan untuk membelai/menyentuh benda)

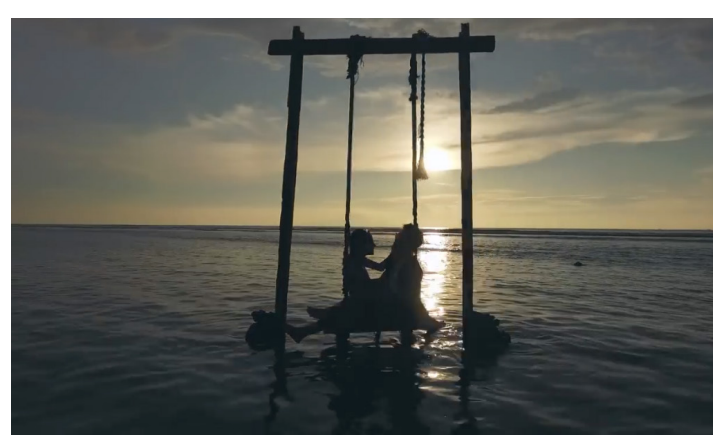

GAMBAR 5. Wonderful Indonesia - Explore The Journey of Romance 60s (Tangan perempuan menyentuh orang lain/lawan jenis)

diri sendiri. Menyentuh diri atau tubuh dianggap sebagai bentuk untuk menunjukkan berharganya tubuh seseorang (Sirikaya \& Sonmez, 2015 ). Sentuhan diri dilakukan untuk menonjolkan kesempurnaan dari bagian tubuh. Misalnya perempuan memegang pipinya dan perempuan memegang pinggulnya untuk menunjukkan bahwa dirinya langsing dan cocok menggunakan pakaian yang ia kenakan (gambar 6).

\section{Function Rank}

Function Rank atau urutan fungsi mengelompokkan perilaku yang ditunjukkan oleh model iklan dan berkaitan dengan fungsi atau pekerjaan yang dilakukannya. Hal ini dapat dilihat ketika laki-laki dan perempuan ditampilkan secara kolaborasi atau bersamaan. Function Rank mempengaruhi pentingnya seseorang di masyarakat

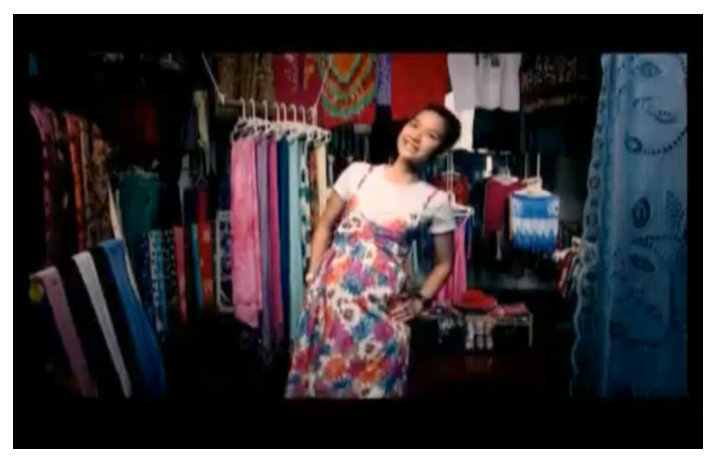

GAMBAR 6. I Love My Indonesia (Perempuan menyentuh pinggulnya) 


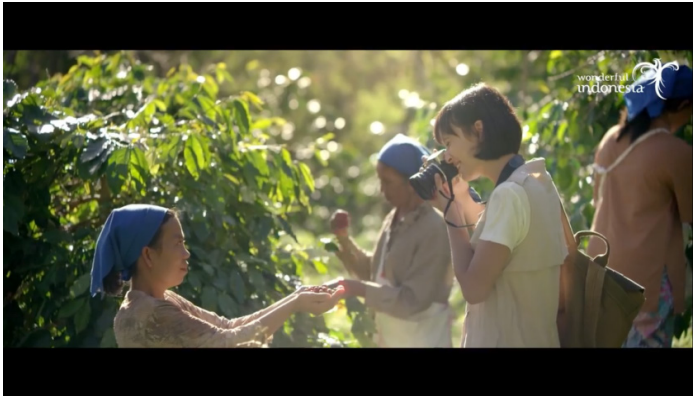

Gambar 7. Explore Further and Higher in the World of Wonders (Perempuan menjadi fotografer)

karena semakin besar tugas yang dilakukan oleh model dalam iklan tersebut menunjukkan mengenai pentingnya sosial orang tersebut. Hubungan antara laki-laki dan perempuan meliputi pekerjaan dan juga peran mereka di dalam kehidupan bermasyarakat. Pada kategori ini, peneliti melihat sosok yang memiliki peran lebih aktif dibandingkan dengan model lain yang berperan pasif.

Urutan fungsi gender dapat dilihat dari pekerjaan serta kegiatan yang dilakukan oleh laki-laki atau perempuan di dalam iklan. Urutan fungsi gender di dalam iklan ditunjukkan dari nilai tugas yang dilakukan oleh model iklan. Sosok yang melakukan pekerjaan memiliki peran aktif sedangkan yang lebih banyak menerima bantuan dianggap melakukan kegiatan pasif. Berdasarkan penelitian sebelumnya yang dilakukan oleh Sirikaya \& Sonmez (2015 ), mengungkapkan bahwa laki-laki lebih banyak membantu perempuan pada aktivitas tertentu. Pada hal ini, perempuan dianggap sebagai sosok yang lemah dan tidak mampu karena lebih bergantung pada laki-laki.

Berdasarkan penelitian terhadap iklan Wonderful Indonesia, terdapat scene yang menunjukkan bahwa laki-laki memiliki peran lebih aktif dibandingkan perempuan ketika mereka ditunjukkan secara bersama. Misalnya dalam video yang menunjukkan ketika seorang perempuan berjalan sendiri atau dengan perempuan lain, ia ditunjukkan dengan membawa kamera dan memotret objek tertentu (gambar 7). Dahulu, fotografer perempuan ialah hal tabu, karena perempuan dianggap makhluk yang lemah dan tidak kuat membawa kamera yang berat (Boer, 2012). Sedangkan pada video tersebut ditunjukkan bahwa perempuan juga mampu menjadi seorang fotografer. Pada scene lain, ketika lakilaki dan perempuan ditunjukkan bersama, laki-laki yang membawa kamera dan memotret objek tertentu, sedangkan perempuan hanya berjalan mengikutinya dibelakang tanpa melakukan hal apapun. Selain itu dalam judul video lain juga ditunjukkan laki-laki berperan sebagai fotografer dan perempuan menjadi objek untuk di foto (gambar 8). Hal ini semakin memperkuat bahwa laki-laki memang memiliki peran dan kuasa yang lebih besar dibandingkan perempuan. Fotografer memiliki kuasa yang lebih tinggi dibandingkan dengan modelnya. Karena fotografer dapat mengatur dan mengarahkan model untuk membuat makna dari gambar yang dibuatnya (Pribadi, 2013).

Penelitian ini tidak seluruhnya sama dengan hasil penelitian sebelumnya yang menunjukkan peran laki-laki lebih tinggi dan perempuan ditunjukkan pada peran stereotipe. Pada iklan audio visual sudah ada perubahan peran perempuan yang meningkat dan lebih beragam (Allan \& Coltrane, 1996). Penelitian ini

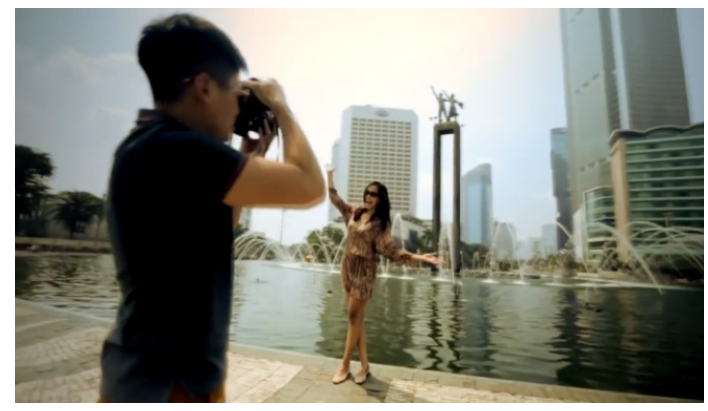

Gambar 8. Wonderful Indonesia - JakartaIndonesia's National and Business Capital (Laki-laki menjadi fotografer, perempuan menjadi objek) 
hampir mirip dengan penelitian Allan \& Coltrane (1996), yang menemukan bahwa ada perubahan pada peran pekerjaan perempuan. Perempuan tidak selalu di tampilakan pada pekerjaan dengan stereotipe tradisional. Dari beberapa sampel iklan, ada yang menunjukkan peran perempuan dan lakilaki sama. Mereka melakukan kegiatan ataupun pekerjaan yang serupa. Misalnya pada bidang olah raga, laki-laki dan perempuan sama-sama ditunjukkan sedang bermain golf dan juga bersepeda. Dibidang pekerjaan, perempuan juga ditunjukkan sebagai seorang sekretaris pada salah satu judul video. Dulunya perempuan memiliki kesempatan yang terbatas, kini perempuan sudah banyak melakukan pekerjaan di ranah publik yang profesional dan bergaji. Pekerjaan tersebut juga merupakan perpanjangan dari pekerjaan domestik seperti guru, sekretaris dan juga bidan (Wirartha, 2000).

Pada salah satu sampel video yang berjudul Indonesia - Country of A Thoudand Faces, ditampilkan bahwa seorang laki-laki bekerja menjadi pelayan/ bellboy yang membukakan pintu untuk seorang pengunjung/ perempuan (gambar 9). Salah satu tugas bellboy ialah memberikan pelayanan dan juga bantuan bagi pengunjung. Pekerjaan menjadi Bellboy cenderung dilakukan oleh laki-laki karena ditunjukkan dengan kata penanda gender (boy) (Wijayanto \&

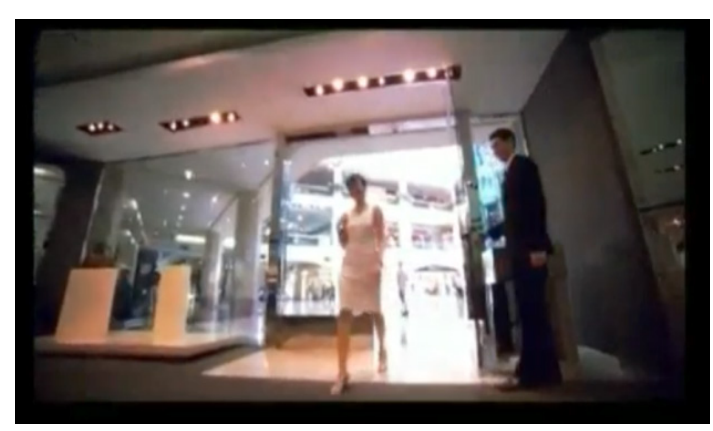

GAMBAR 9. Indonesia - Country of A

Thoudand Faces (Laki-laki menjadi pelayan, membukakan pintu untuk perempuan)

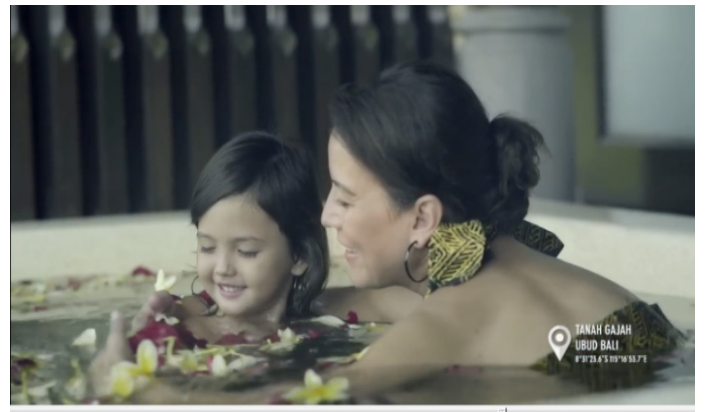

GAMBAR 10. Wonderful Indonesia Family (Japanese Version) (Ibu dan anak perempuan berendam setelah melakukan spa)

Fauziati, 2006). Laki-laki ditunjukkan pada pekerjaan yang menggunakan kekuatan fisik. Di video tersebut lakilaki ditunjukkan menggunakan kekuatan fisiknya untuk membantu perempuan yang lewat dengan membukakan pintu.

\section{The Family}

Family/keluarga inti beranggotakan ayah, ibu dan anak sebagai bagian dasar dari organisasi sosial masyarakat. Keluarga inti seringkali digambarkan dalam periklanan. Penggambaran keluarga di dalam iklan juga menunjukkan peran gender yang dapat dilihat dari kegiatan ayah, ibu serta anak. Melalui kebersamaa keluarga dapat dilihat bagaimana hubungan antar anggota keluarga tersebut. Di dalam keluarga, masing-masing anggota memiliki peran. Beberapa video Wonderful Indonesia yang telah dianalisis terdapat video yang menggambarkan kebersamaan keluaga.

Ada video yang menunjukkan kebersamaan keluarga. Video tersebut menggambarkan kedekatan hubungan antara ibu dengan anak perempuannya. Ibu dan anak perempuan seringkali ditunjukkan melakukan beberapa kegiatan bersama seperti spa (gambar 10), berlatih menenun dan juga yoga. Kegiatan tersebut mereka lakukan tanpa ada laki-laki yang mengikutinya (ayah dan anak laki-laki). Pada setiap iklan pariwisata layanan spa/terapis pijat 


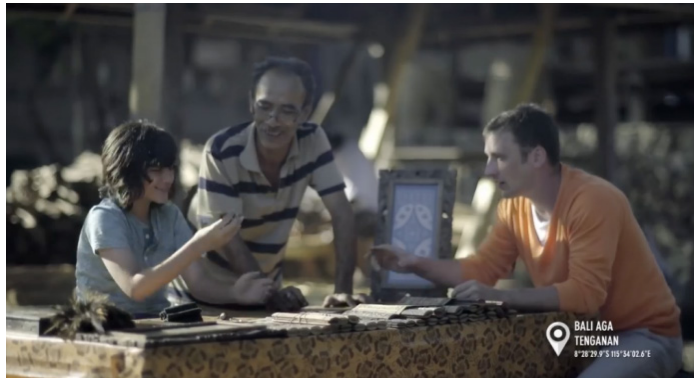

GAMBAR 11. Wonderful Indonesia Family (Japanese Version) (Ayah dan anak laki-laki latihan melukis motif kain).

selalu didominasi oleh perempuan (Sun, 2017). Terapis pijat merupakan tenaga kerja feminin dan biasa dilakukan oleh perempuan karena sifatnya yang peduli dan cenderung memelihara diri. Selain subjek yang melakukan spa, objek yang di pijat pun juga di dominasi oleh perempuan. Laki-laki tidak banyak ditunjukkan dalam melakukan terapi pijat. Meskipun terapis pijat/spa merupakan proses penyembuhan fisik bagi semua orang, namun menurut Sun (2017) spa memiliki makna budaya yang berbeda. Bagi perempuan spa dilakukan untuk memanjakan dan juga merawat diri, sedangkan bagi laki-laki pijat refleksi dilakukan untuk merelaksasikan tubuh setelah bekerja.

Berkebalikan dengan ibu yang sering ditunjukkan bersama dengan anak perempuannya, ayah lebih sering ditunjukkan melakukan kegiatan dengan anak laki-laki.Ayah dan anaklaki-lakipada video ditunjukkan melakukan beberapa kegiatan bersama, seperti berjalan-jalan, latihan melukis motif kain (gambar 11), dan berenang. Menurut penelitian Rubin, Dwyer, Booth-LaForce, Kim, Burgess, \& Rose-Krasnor (2004) waktu ayah untuk berinteraksi dengan anak-anak lebih sedikit, dan interaksi yang dilakukan lebih banyak melibatkan kegiatan fisik di luar ruangan. Sebab itulah ayah lebih sering ditunjukkan melakukan kegiatan dengan anak laki-laki, karena menurut stereotipe tempatnya perempuan ialah dirumah atau

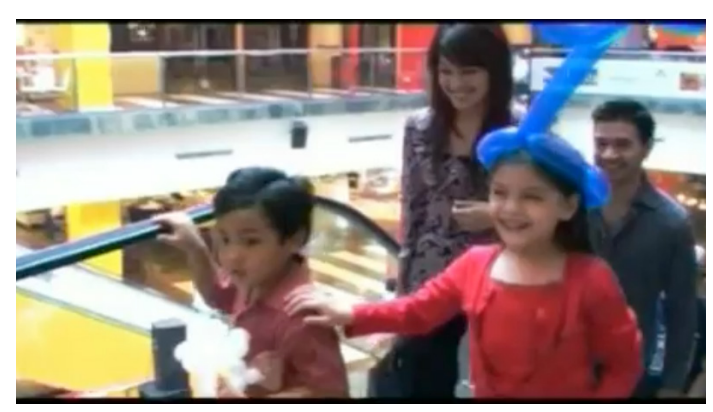

GAMBAR 12. Indonesia - Country of A Thousand Faces (Ayah berada pada posisi paling belakang).

di dalam ruangan (Belknap \& II, 1991).

Ayah memiliki peran yang besar di dalam keluarga, selain berperan sebagai suami dan kepala rumah tangga ia juga menjadi pelindung (Gunarso \& Gunarso, 2004). Pada video lain, Ayah ditunjukkan berjalan berada di paling belakang (gambar 12). Hal tersebut menunjukkan bahwa ayah melindungi anggota keluarganya. Menurut Goffman, ayah yang digambarkan diluar anggota keluarganya berusaha ditunjukkan sebagai sosok yang melindungi dan menunjukkan otoritasnya atas keluarga (dalam Sirikaya \& Sonmez, 2015 ).

\section{e. Ritualization of Subordination}

Berdasarkan stereotip tradisional, perilaku menurunkan diri secara fisik dianggap sebagai subordinasi sedangkan menjaga tubuh untuk tetap tegak dengan kepala tinggi merupakan tanda superioritas dengan percaya diri. Tindakan subordinasi dapat dilihat pada gambar iklan yang meliputi sikap membungkukkan badan atau satu lutut, pinggul miring, menekuk kepala, tersenyum, mengejek orang, memperluas lengan, serta memegang tangan lawan jenis.

Posisi yang sering ditunjukkan dalam iklan ialah berbaring di tempat tidur atau lantai. Pada video Wonderful Indonesia, perempuan dan anak-anak ditunjukkan lebih rendah dari pada lakilaki. Hal tersebut dapat dilihat dari hasil penelitian yang ditunjukkan pada iklan 
video Wonderful Indonesia. Berdasarkan penelitian yang dilakukan oleh Goffman (1979) terhadap gender di media, ditunjukkan bahwa perempuan dan anakanak lebih sering ditunjukkan berada di tempat tidur atau di lantai. Dari sepuluh sampel video yang telah dianalisis tujuh diantaranya menunjukkan perempuan berada ditempat tidur untuk melakukan body spa, bersantai di dekat kolam renang dan istirahat dikamar hotel serta ada juga yang duduk dan tiduran di pasir pantai. Anak-anak juga ditampilkan bermain di lantai. Ditunjukkan berada di tempat tidur dan dilantai menjadikan seseorang berada pada situsasi sosial yang yang lebih rendah dan lebih rendah dengan siapapun yang berada di kursi atau berdiri. Lantai juga menjadi tempat yang kurang bersih (Goffman, 1979).

Dari iklan-iklan tersebut, tidak seluruhnya perempuan yang ditampilkan sedang bersantai dan berbaring. Namun ada juga yang menunjukkan lakilaki berbaring santai. Ketika laki-laki ditunjukkan berbaring, ada juga seorang perempuan yang ditunjukkan sedang bersantai bersamanya di sampingnya (gambar 13). Hal tersebut menunjukkan bahwa laki-laki dan perempuan juga ditunjukkan setara, dengan melakukan kegiatan yang sama.

Senyum menunjukkan hubungan orang yang ada di dalam frame, atau dengan pemirsa. Pada penelitian yang

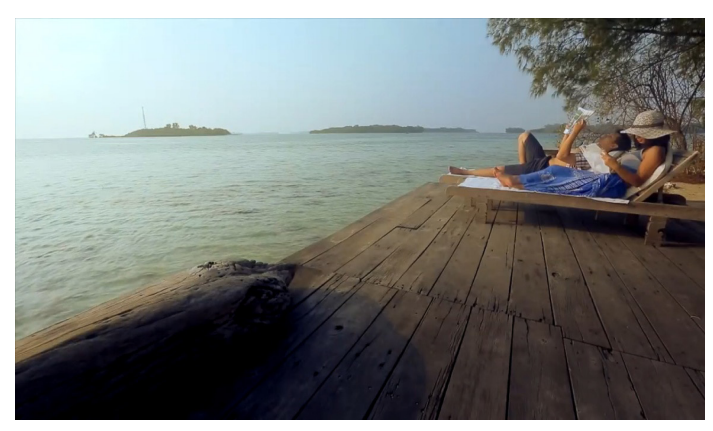

GAMBAR 13. Wonderful Indonesia - Jakarta- Indonesia's National and

Business Capital (Laki-laki dan perempuan ditampilkan pada kegiatan yang sama)

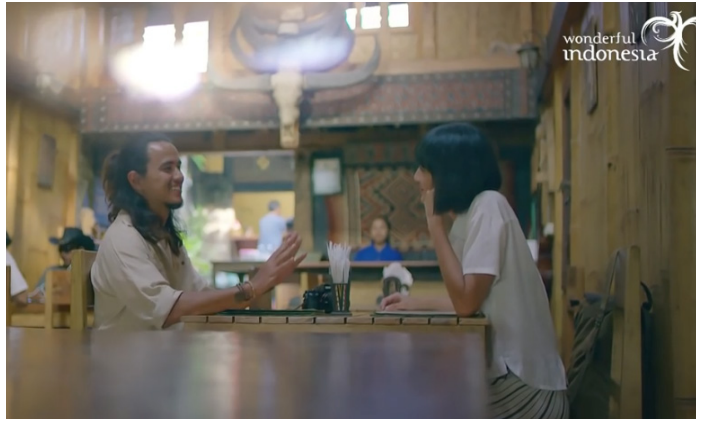

GAMBAR 14. Explore Further and Higher in the World of Wonders (Lakilaki tersenyum ketika bersama dengan perempuan)

dilakukan Sirikaya \& Sonmez (2015) terhadap iklan brosur pariwisata telah menunjukkan bahwa dibandingkan perempuan, laki-laki lebih sering ditunjukkan dengan sikap yang serius. Penelitian ini sama dengan penelitian tersebut, perempuan ditunjukkan dengan selalu tersenyum dan terlihat ramah. Sedangkan laki-laki lebih sering ditunjukkan dengan sikap serius. Hal tersebut menunjukkan bahwa perempuan lebih sering menunjukkan hubungan dan mengirim isyarat nonverbal serta lebih ekspresif dibandingkan dengan laki-laki. Ada beberapa iklan yang juga menunjukkan laki-laki tersenyum. Pada hal ini, biasanya laki-laki ditunjukkan satu frame dengan perempuan yang berada di sekitarnya (gambar 14). Dari video tersebut dapat dilihat bahwa perempuan akan memancing laki-laki untuk tersenyum. Sosok perempuan di dalam iklan, digunakan untuk mengurangi ketegangan dalam penjualan produknya dan juga agar terlihat lebih santai (Masse \& Rosenblum, 1988).

\section{Licensed Withdrawal}

Licensed withdrawal atau suatu penarikan diri, ialah karakter yang tidak dapat menguasai situasi sehingga secara psikologis ditarik dari situasi secara umum, dan mereka tidak berorientasi serta lebih bergantung pada orang lain 
(Sirikaya \& Sonmez, 2015 ). Menurut Belknap \& II (1991) hal ini bisa ditandai dari sikap dan perilaku yang ditunjukkan seperti menutup wajah, merasa takut, menyesal, malu-malu, tertawa, menggigit jari, mengalihkan tatapan mata dari lawan bicara, berbaring dengan kaki ditekuk, meringkuk serta nuzzling. Berdasarkan penelitian yang dilakukan oleh Goffman (1979), perempuan dalam iklan ditunjukkan lebih sering tidak berorientasi di dalam situasi sosial dan bergantung pada perlindungan serta niat baik orang lain dibandingkan dengan laki-laki.

Pada sepuluh sampel iklan Wonderful Indonesia yang telah dianalisis, beberapa diantaranya menunjukkan hal yang sama dengan penelitian Goffman (1979). Ada dua video yang terdapat adegan perempuan menutup mulut atau sebagian wajah dengan jari tangannya. Pada dua judul video tersebut ditunjukkan perempuan yang sedang tersenyum atau tertawa dengan menutup mulutnya dengan tangan (gambar 15).

Menutup mulut dengan tangan bisa menjadi bentuk kelemahan karena seperti tindakan yang tidak dapat menyembunyikan padahal ada sesuatu yang ia sembunyikan.

Selain itu, pada beberapa video juga ditunjukkan bahwa perempuan tertawa dalam adegan. Video tersebut dua orang perempuan sedang mengobrol dan saling tertawa. Sedangkan pada video lain,

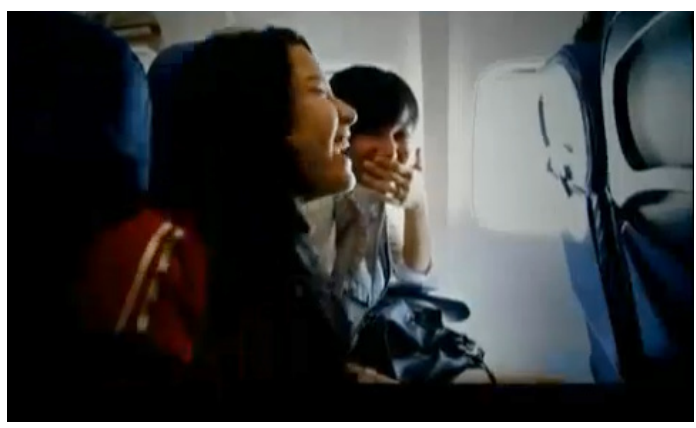

GAMBAR 15. I Love My Indonesia (perempuan tertawa dengan menutup mulutnya)

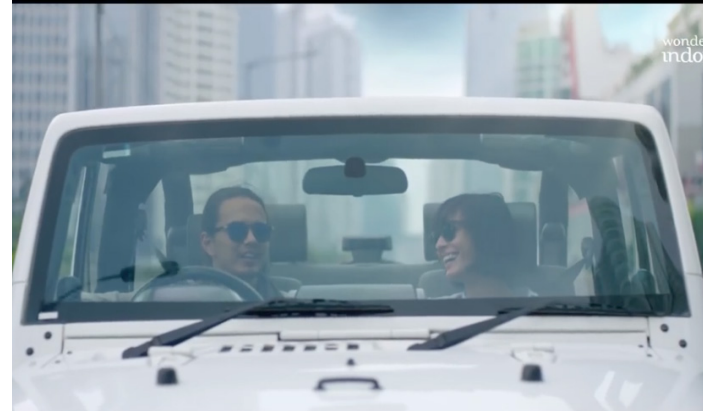

GAMBAR 16. Further and Higher in the World of Wonders (Perempuan tertawa, lakilaki tidak)

ada adegan yang menunjukkan seorang laki-laki yang sedang menyetir sambil mengobrol dengan seorang perempuan dan perempuan tertawa (gambar 16). Perempuan ditampilkan tertawa pada beberapa adegan, menunjukkan bahwa ia berusaha menarik diri dari situasi sosial melalui respon emosional (Goffman, 1979). Tertawa menunjukkan respon emosional berlebih yang menyebabkan kehilangan kontrol. Dari beberapa video, tidak hanya perempuan yang ditunjukkan tertawa. Ada pula scene yang menunjukkan perempuan dan laki-laki tertawa ketika sedang bersama (gambar 17).

Tatapan menjadi salah satu perilaku yang digunakan untuk memberikan sinyal koneksi. Dari beberapa video yang telah dianalisis, ada beberapa adegan yang menunjukkan bahwa laki-laki menatap perempuan, sedangkan perempuan

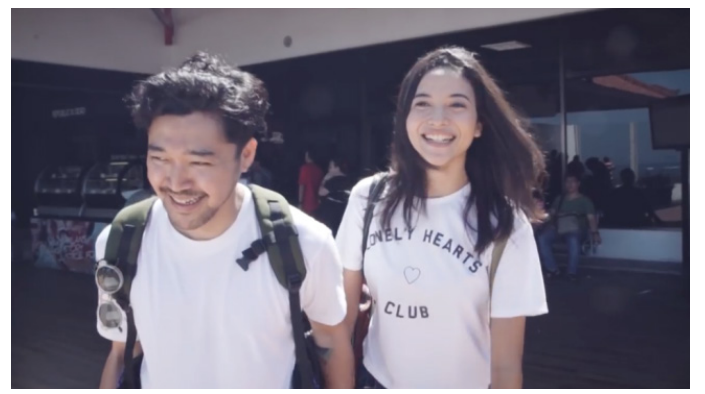

GAMBAR 17. Wonderful Indonesia -

Explore The Journey of Romance 60s

(Perempuan dan laki-laki sama-sama tertawa dalam adegan) 
membuang tatapan pada arah lain. Mengalihkan pandangan dari tatapan orang lain juga merupakan bentuk dari penarikan diri dari situasi tertentu dan juga agar terlindungi dari pengawasan (Goffman, 1979). Perempuan pada video tersebut menjadi pihak pasif sedangkan laki-laki digambarkan sebagai orang yang aktif memberikan sinyal koneksi.

\section{SIMPULAN}

Penelitian mengenai gender di iklan sudah banyak dilakukan. Penelitian seperti yang dilakukan oleh Belknap \& II (1991), Bell \& Milic (2002) dan Sirikaya \& Sonmez (2015) lebih meneliti gender secara kuantitatif serta lebih fokus ke media cetak. Oleh karena itu, penelitian ini dilakukan untuk mendeskripsikan penggambaran khususnya perempuan di iklan audio visual. Sesuai dengan pernyataan Belknap \& II (1991) mengenai iklan cetak, penggambaran stereotipe berubah lebih lambat dibandingkan dengan iklan audio visual, hal inilah yang ditunjukkan dalam hasil penelitian ini. Pada kategorisasi feminin touch, the family dan juga licensed withdrawal perempuan masih ada yang ditunjukkan pada peran stereotipe seperti menggunakan tangannya untuk menyentuh diri, melakukan spa/kegiatan feminin. Sedangkan perempuan pada kategori relative size, function rank dan ritualization of subordination sudah ada yang ditunjukkan memiliki peran yang setara dengan laki-laki seperti status sosial yang sama, perempuan yang bekerja diranah publik dan ditunjukkan pada kegiatan yang sama dengan lakilaki.

Untuk penelitian selanjutnya diharapkan peneliti dapat melihat penggambaran laki-laki dalam iklan Wonderful Indonesia dengan kategorisasi gender advertisement menurut Goffman. Atau juga dapat meneliti gender pada iklan pariwisata Indonesia yang difokuskan di media cetak.

\section{DAFTAR PUSTAKA}

Allan, K., \& Coltrane, S. (1996). Gender Displaying Television Commercials: A Comparative Study of Television Commercials in the 1950s and 1980s. Sex Roles , 185-203.

Belknap, P., \& II, W. M. (1991). A Conceptual Replication and Extension of Erving Goffman's Study of Gender Advertisements. Sex Roles, 103-118.

Bell,P., \& Milic, M. (2002). Goffman's Gender Advertisements revisited: combining content analysis with semiotic analysis. Visual Communication, 203-222.

Boer, K. M. (2012). Nude Photography, Eksploitasi Tubuh Pengatasnamaan Seni. Jurnal Komunikator .

Goffman, E. (1979). Gender Advertisements. New York: Harper \& Row.

Gunarso, S. D., \& Gunarso, Y. S. (2004). Psikologi Praktis: Anak, Remaja, dan Keluarga. Jakarta: PT BPK Gunung Mulia.

Kusuma, R. S., \& Vitasari, Y. (2017). Gendering the Internet: Perempuan pada Ruang Gender yang Berbeda. Jurnal Ilmu Komunikasi , 125-142.

Lombard, M., Duch, J. S., \& Bracken, C. C. (2002). content analysis in mass communication assessment and reporting of intercoder reliability. Human Communication Research, 587-604.

Masse, M. A., \& Rosenblum, K. (1988). Male and Female Created They Them: The Depiction of Gender In the Advertising of Traditional Women's and Men's Magazines. Women's Studies Int. , 127144.

Pribadi, M. H. (2013). Konstruksi Sensualitas Model Perempuan Pada Komunitas "Bukan Fotografer".

Pritchard, A. (2001). Tourism and Representation: a Scale for Measuring Gendered Portrayals. Leisure Studies , 79-94.

Rubin, K. H., Dwyer, K. M., Booth-LaForce, C., Kim, A. H., Burgess, K. B., \& Rose-Krasnor, L. (2004). Attachment, Friendship, and Psychosocial Functioning in Early Adolescence. 
Early Adolescence, 326-356.

Sirikaya, E., \& Sonmez, S. (2015 ).

Gender Images in State Tourism BrochureAs:An Overlooked Area in Socially Responsible Tourism Marketing . 353-362.

Sun, Z. (2017). Exploiting Femininity in a Patriarchal Postfeminist Way: A Visual Content Analysis of Macau's Tourism Ads. International Journal of Communication, 2624-2646.

Wagner, L. C., \& Banos, J. B. (1973). A Woman's Place: A Follow-up Analysis of the Roles Portrayed by Women in Magazine. American Marketing Association .

Wijayanto, A., \& Fauziati, E. (2006). Sexist Language dalam Buku LKS Bahasa Inggris untuk Siswa SLTP di Surakarta. Jurnal Penelitian Humaniora , 133151.

Wirartha, I. M. (2000). Ketidakadilan Gender yang Dialami Pekerja Perempuan di Daerah Pariwisata. Jurnal Sosial-Ekonomi Pertanian . 